\title{
INSIGHTS FROM THE ARCHIVES: BRITISH DEVELOPMENT AID AND ENGLISH LANGUAGE TEACHING
}

\author{
Angela M. Crack
}

\begin{abstract}
Britain has funded English language teaching (ELT) initiatives in developing countries for decades, despite changes in government and a series of substantial overhauls in the administration of development aid. This article reveals the relevance of ideational factors in explaining how ELT remained a key part of Britain's aid policy during a period of significant domestic and international change. It uses constructivist institutionalism to interpret an extensive range of evidence from government archives spanning a twenty-two year period (1964-1986). It sheds light on how and why certain ideas become normalised and institutionally embedded over time, and become the cognitive template through which key actors form policy preferences.
\end{abstract}

Key words: Political Discourse, Language Policies, Language Learning, Education.

The notion that ELT is a worthwhile investment of British aid money has long been a matter of cross-party consensus, and funding has been pumped into ELT initiatives across the world. The origin and development of the policy preference for ELT has received little analysis, with few exceptions (Phillipson 2006). There are three main disciplines in which it might be expected that relevant research would be located: language studies and political and development studies. As far as language studies is concerned, the study of Language and Development began to flourish a mere twenty years ago (Coleman 2011, 22). Much of the focus has been on contemporary discourse and policy on ELT, particularly initiatives that are promoted by the UK's Department of International Development (DFID, established 1997. E.g. Appleby 2010; Coleman 2010; Erling and Seargeant 2013). In political/development studies, research on the history of UK aid has either ignored ELT or only mentioned it in passing (e.g. Burnell 1991; Ireton 2013; Killick 2005). From a constructivist perspective, this 'knowledge gap' inhibits sophisticated understanding of the deep-rooted ideational dynamics that guide and frame development policy regarding ELT. Prima facie, the reasons advanced by British policy-makers about the benefits of funding ELT might appear to be an 'objective' calculation of material interests. However, constructivists challenge commonly held 
assumptions that social reality is constituted by material factors, and argue that the thinking of policy-makers is 'not just a mechanistic function of uninterpreted conditions around them' (Parsons 2016, 446). They maintain that policy-making is shaped by intersubjective understandings about social reality that are reproduced by actors, institutions and processes (Wendt 1999).

For the first time, this article uses constructivist institutionalism to trace the history of UKfunded ELT initiatives, drawing on evidence from government archives spanning a twentytwo year period (1964-1986). It examines official documents pertaining to development aid, to uncover the government's position on ELT. This is a departure from the traditional approach to language policy research, whereby language/educational policy texts are analysed to uncover national discourses. The article underlines the relevance of ideational factors in explaining how ELT became normalised as a priority area in Britain's development aid. In so doing, it sheds light on how certain policy preferences become institutionally embedded, and provides an enriched understanding of the ideational and historical context within which contemporary policy-makers operate.

I argue that long-term commitment for ELT was underpinned by consensus amongst the political elite that the promotion of English was advantageous for developing countries and the UK. Discussions about ELT were framed by a language ideology about the unique characteristics of English, which was reinforced by American-influenced political, economic, technological and cultural global trends. There was broad agreement that the best way to maximise the effect of limited resources was to target aid strategically, such as funding teacher training and curriculum development. Britain was thought to have a comparative advantage in this regard. There was a shared view about the nature of Britain's national interests in a postcolonial age (as least as far as ELT was concerned), particularly concerning the need to project 'soft power' over the Commonwealth. Notions of moral duty were commonly attached to practices of aid-giving, and Britain was thought to be well-positioned to improve the lives of the poorest by increasing access to ELT. These perceptions were reinforced by appeals from developing countries for funding for ELT initiatives. These assumptions became entrenched over time and formed the cognitive template through which the political elite perceived the benefits of providing aid for ELT. It was deeply embedded and so was resistant to change. In other words, policy was ideationally path-dependent. 
The case study illustrates the analytical value of constructivist institutionalism in exploring the institutional dynamics that shape language and education policies. It contributes to historical research on language policy that examines how elites shape policy discourses (Tollefson 2015, 142). It builds on research about the construction of Anglocentric narratives that legitimise the promotion of English in the non-West, based on perceptions of multilingualism as a deficiency that causes social and economic 'backwardness' (Wiley 2006, 140-143). It also builds on research published in previous editions of this journal about Anglocentrism and the influence of colonial histories and former colonial powers on the language and education contexts of postcolonial states (Boyle 2010, Evans 2002, Louw 2010, Tupas 2014). As will be further discussed in the conclusion, constructivist institutionalism is not uniquely applicable to the UK context. It could be readily deployed to investigate the evolution of policies on development aid and language teaching in other countries.

The article proceeds as follows. First, the theoretical framework is outlined. Second, there is an overview of the methods. Third, some brief comments are made about the history of the administration of development aid over the period under examination, in order to provide some context to the ensuing archival analysis. The fourth section discusses how preferences for the strategic targeting of ELT aid were repeatedly expressed in the archival material. The fifth section analyses the core themes of national interest and moral duty in the archival documents. The article concludes with some reflections on the relevance of the findings for future research on how ideational path-dependency could account for the framing and design of contemporary language education initiatives.

\section{Interpreting the Archives Through the Lens of Constructivist Institutionalism}

This article is informed by ideational approaches to political analysis, which reject the notion that social reality is constituted by material conditions. Rather, the political and social world is constructed by the ideas of the actors who inhabit it, and the intersubjective understandings that they share with others. Focusing on ideas enables the analyst to interrogate the role of actors in reproducing discourses that shape political decisions and establish policy trajectories. It also permits a deeper understanding of how ideas are embedded in the design and development of institutions. Constructivist institutionalism is a distinct strand of this broad theoretical tradition. 
Institutions can be broadly defined as 'formal or informal procedures, routines, norms and conventions embedded in the organizational structure of the polity or political economy.' (Hall and Taylor 1996, 938) Constructivist institutionalism emerged from critiques of different branches of 'new institutionalism' (Bell 2011; Hay 2006; 2010; 2016). The latter is commonly defined with reference to Hall and Taylor's (1996) categories of historical institutionalism, rational choice institutionalism and sociological institutionalism.

Constructivist (see also discursive) institutionalism is distinguished by its preoccupation with the role that ideas play in shaping institutions and processes (Schmidt 2008). Constructivist scholars criticised new institutionalism for an excessive focus on institutions at the expense of individual actors, which produced a structuralist account that downplayed the salience of agency in shaping political outcomes. Moreover, constructivists argued that new institutionalist scholarship tended to avoid in-depth examination of how actors' perceptions, preferences and motivations are moulded over time and inform policy (Ross 2013).

Constructivists maintain that actors are not analytically substitutable and their interests cannot be deduced from their institutional context (Hay 2010, 68).

For example, rational choice scholars assume that states are motivated by self-interest, which is understood to be 'necessary' or 'inevitable' given external conditions. In the context of the present study, it could be assumed that Britain's attempts to push its advantage in ELT are 'inevitable' responses to a 'self-help' international system where states are compelled to compete to enhance their power and influence. The problem with this position is that it implicitly assumes that interests are fixed and exogenously given. As Hay argues, rationalist accounts 'are typically part of an analytical rather than a genuine ontology in that they are chosen less for their ontological credibility than for the analytic convenience they afford' (2016, 529). Rationalism obscures how political processes are authored and elides the role of the agents that produce and reproduce ideas that become institutionalised. To return to the words of Hay, 'this is to deny agency, contingency and, in the process, the very politics which constructivism seeks to identify and interrogate' (2016, 529). In contrast, constructivists contend that social and political realities are constructed by actors that develop intersubjective understandings about the world, and develop practices on the basis of these understandings. They focus on how perceptions of interests are generated and rendered actionable (Wendt 1999, 113-135). Interests are not taken-for-granted, but are the explanandum. By placing ideas on the centre stage, constructivism enables us to understand 
institutions as comprised of a complex blend of intersubjective understandings that shape institutional development and guide policy pathways (Blyth 2002).

A particularly valuable contribution of constructivist institutionalism is the notion of 'ideational path-dependence', which describes how institutions are forged by a set of ideas that become so deeply embedded that they exert an independent path-dependent effect (Cox 2004). Such ideas become the cognitive template through which decision-makers and other key actors understand their identities, conceive of their interests, and undertake strategic actions (Hay 2010, 69). This approach may be of interest to scholars who interrogate the role of ideology on language and education policy (e.g. Ricento 2000). Language ideology is defined as 'sets of beliefs about language articulated by users as a rationalization or justification of perceived language structure and use.' (Silverstein 1979, 193). Incorporating the concept of language ideology in a constructivist institutionalist framework provides a powerful lens for interpreting how language and education policies are shaped. For example, it will be seen in the archival analysis below that the policy discussions were framed by a metanarrative of English as synonymous with modernisation and development (Pennycook 2014). English was associated with economic and political development, and scientific and technological progress. English was thought to have the potential to unite culturally diverse territories and foster regional and international stability. The inexorable global spread of English, associated with the growth in the hegemonic influence of the USA, seemingly gave credence to Anglocentric language ideology (Wright 2016, chapter 7). I argue that the cognitive template of policy-makers were fundamentally shaped by an Anglocentric language ideology, along with ideas about national interest, moral duty and the strategic targeting of aid. The case study demonstrates how constructivist institutionalism can offer language studies an explicit vocabulary to theorise the path-shaping power of ideas.

\section{Methods}

This research was conducted during October 2015-March 2016 at The National Archives (TNA) in Kew, London. TNA contains an enormous collection of records from British government departments, ranging from reports, parliamentary papers, letters (official and private), telegrams, despatches, pamphlets, memos, notes and clippings. A small proportion of this material is available online, but most (including all the documentation consulted as part of the research) are only accessible by visiting the archive in person. The research is based on records created or inherited by the Department of Technical Co-operation and of 
successive Overseas Development bodies over the period 1964-1986. It is also based upon records of the Foreign and Commonwealth Office (FCO) over the same time period, since the FCO 'have always been well represented' when decisions were taken regarding aid allocation, country policy and major projects (Winpenny 1991, 36). Note that the analysis stops here because of restrictions on full public access to the archives after this date. Correspondence received by government departments is numbered and categorised into files by TNA, and catalogued online. The database for this research was compiled using TNA's online search engine and filtering the results by the relevant date range and taxonomy subjects. Each file contained correspondence that was collated over a period of up to two years, and the most relevant files were selected after a manual scan of the contents. The analysis is primarily based on 86 files, after which it was judged that saturation point had been reached. Key contents of the files were photographed, so that the material could be thematically coded outside of the archive. I undertook three complementary methods to ensure that the analysis was robust. First, I kept a research diary to record my search strategies and emerging analysis of the archival material. I used the diary to reflect upon the evidentary value of the material and to avoid the risk that I interpret the findings in a way that supported my biases (Johnson 2013, 128). Second, I sought peer review of my analytical method by inviting two colleagues to join me for a trip to TNA, who are experienced in archival research and engaged on a related project. We analysed a sample of 15 files and discussed emergent themes. Third, I tested the credibility of the findings by submitting my paper for comment to the founder/curator of The ELT Archive at the University of Warwick. He is a leading expert on the history of ELT who presides over an extensive collection of material that is largely constituted of British texts and documents.

\section{History of the Administration of Development Aid, 1964-1979}

It was not until October 1964 that a single Ministry was established to administer overseas aid, an initiative of the newly-elected Labour government. Named the Ministry of Overseas Development (ODM), it assumed the responsibilities of several government departments, including the former Department of Technical Cooperation. It was established as a separate department from the FCO with the express intent to ensure that foreign policy considerations did not swamp development policy (Hewitt 1978). The first White Paper of the new Ministry in 1965 stated that the primary objective of ODM was to raise living standards in developing countries, with particular focus on the Commonwealth and Dependent Terrorities. ODM 
claimed to work with potential recipient countries to identify worthwhile areas for projecttied funding, and decisions would be made based on a judgement of what would be most likely to be effective in achieving its goals.

Following the election of the Conservatives in 1970, ODM was renamed the Overseas Development Administration (ODA) and moved to the FCO. The re-organisation sent a clear signal that the new government intended aid policy to be subservient to foreign policy objectives. Despite the reorganisation, 'the policies, practices and staff largely remained intact' (Barder 2005, 7). The election of Labour in 1974 brought about another change in institutional status, where a separate Ministry was re-established (reverting back to the title ODM). This demonstrated the higher political profile that Labour gave to development, most notably articulated in the 1975 White Paper: The Changing Emphasis in British Aid Policies: More Help for the Poorest (Ministry of Overseas Development 1975). It signalled a shift in development aid towards targeting the poorest (particularly rural) groups rather than simply funding discrete development/technical assistance projects (Killick 2005, 79-80). These principles underpinned the stated mission of UK aid until the establishment of DFID (Ireton 2013, 43). In addition, Wilson introduced an Aid and Trade Provision that linked aid to nonconcessionary export credits tied to the procurement of British goods and services (Barder 2005, 9).

When the Conservatives were returned in 1979, the Ministry was downgraded to a department of the FCO and rechristened the ODA.The aid budget was slashed as part of a wide programme of public expenditure reform. A review of aid policy was conducted in 1981, which concluded that greater emphasis should be given to political, industrial and commercial objectives, whilst still retaining focus on the Commonwealth. In fact, as the Aid and Trade Provision illustrates, instrumental motivations had always driven aid policy to some degree. However, even during the Thatcher years, altruistic rhetoric about the UK's responsibilities to less developed countries accompanied the focus on the national interest. As will be seen, these dual foreign policy aims shaped discussions and decisions about the promotion of English through development aid in profound ways. We now turn to the archival analysis, which is the subject of the next two sections.

\section{Strategic Targeting of ELT Aid}


A consistent finding in the archival material, across different governments, is that discussions about Britain's support of ELT were framed by ideas about the 'strategic' targeting of aid. 'Unprecedented funding was put into the promotion of ELT' in the 1960s (Smith 2016), including funding to improve English teaching in the Commonwealth. Aid for ELT was underpinned by a belief in the "well-nigh insatiable demand in the developing Commonwealth for the teaching of English' (in the words of the ODM Parliamentary Undersecretary of State; Taylor 1965). An official in the Cultural Relations Department wryly observed that ELT was so often on the agenda because: 'It is almost inevitable that every British Minister who visits African countries (and also Lusophone countries) will be faced with requests for an increase in ELT or the provision of a new facility and it is equally almost inevitable that he will promise to see what can be done.' (Sharland 1981) There was considerable demand for teaching provision even from countries where English was not part of the national heritage. English was seen as a 'common sense' way to raise the living standards of ordinary people: 'To many people of even elementary education in Latin America, English is a highly desirable second language in view of the improved job opportunities which almost automatically follow.' (Turner 1971)

The British Council was a key plank in the delivery of ELT-related aid. By the mid-60s, ODM undertook to provide more than one third of the British Council's grant-in-aid. One of the outcomes was the British Council's scheme Aid for Commonwealth English (ACE), which was designed to produce ELT specialists who could provide expert advice to Commonwealth countries. An associated initiative was the scheme for Aid for British for Commonwealth Science Teaching (ACTS). Further, the British Council was tasked with administering ODM funds in the expansion and improvement of ELT educational facilities in developing countries. This included the development of regional ELT centres, which trained local teachers and provided guidance on 'modern techniques in language teaching' (British Council and Ministry of Overseas Development Working Party 1966). It also assumed responsibility for teaching posts in non-Commonwealth countries and the Indian subcontinent, providing training opportunities in the UK and services for international students, amongst a plethora of other activities with relevance to ELT. ODM had responsibility for recruiting teachers for developing Commonwealth countries (mainly under the Overseas Services Aid Scheme). Around 300 such teachers were appointed through the Ministry by the first two years of its establishment. Other forms of ODM assistance in the teaching and learning of English included the financing of the Centre for Educational Teaching Overseas, 
Commonwealth Teacher Training bursaries and student scholarships. In short, the broad policy approach to ELT was to concentrate on capacity-building, materials and infrastructure.

In 1972, the English as a Foreign Language Scheme (EFL) was launched alongside existing means of support to provide specialist advisers in key posts in non-Commonwealth countries to support the teaching of English. The scheme was inspired by the ACE model of providing expertise to develop indigenous ELT capacity. Similar to the targeted approach that characterised Labour ELT policy, it was designed to 'operate at senior levels and in areas where the multiplier effect of aid is greatest - e.g. teacher training, the development of materials and syllabuses, and inspectorial and advisory services.' (Overseas Development Administration and British Council 1971) This reinforced the practice of disbursing ELTrelated aid strategically.

ODM was guided in its funding decisions by strategic considerations, and ELT was no exception. To quote from correspondence from office of Reg Prentice (Secretary of State for Overseas Development 1975-76) with regard to ELT: 'To exert the maximum leverage, we try to concentrate our aid at a fairly advanced level.' (Douglas 1975) ODM maintained the focus on the provision of expertise and capacity-building, most particularly in Commonwealth countries. The teaching of English in the host countries created a cadre of trained personnel who had a great stake in the perpetuation and penetration of English, increasing the body of support for the continuation of aid (Dua 1996, 581).

In an echo of ODM's assessment of the appetite for ELT in the mid-1960s, ODA declared that development aid faced a major challenge: 'an enormous and unquenchable demand for the English language.' (Iredale 1986) It was declared that ' $[\mathrm{t}]$ here is no aid-worthy country that does not need and want some form of ELT support.' (Macmillan 1982) Appeals for aid from recipient countries reinforced the embedded language ideology that held that English was inseparable from political and economic progress. It was argued that it was impossible to meet an infinite demand, and so ELT needed to be deployed strategically.

Senior figures agreed that ELT initiatives provided an excellent return on investment. For instance, an account of a conference in Nairobi reveals that 'one of the points made most forcibly by a number of Heads of Mission... was the importance of English language teaching as an instrument of British influence and the great benefits which could accrue to us in nonAnglophone countries in Africa for minimum outlay.' (Robson 1981) ELT provided an 
opportunity to cultivate the elite who were more likely to access English tuition. As the Controller of the Africa and Middle East Division in the FCO observed: 'The people learning English in Angola and Mozambique today are likely to be extremely important in their own countries and in Southern Africa as a whole. We have the opportunity of entering the English language teaching field at an early and extremely influential stage.' (Sharp 1981)

One of the most significant means by which ODA sponsored the learning of English was the Key English Language Teaching (KELT) programme, which provided over 150 experts in various countries, who were seen to 'form an integral part of our aid projects, frequently contributing their skills to other elements of the aid programme.' (Iredale 1986) Following the funding strategy of previous ODM/ODA initiatives, KELT was primarily targeted towards curriculum development and teacher training to ensure that the aid had a long-term impact. This included universities and institutes of public administration as well as schools.

However, the Conservative government was ideologically committed to free-market norms, and implemented severe cuts to the British Council's grant-in-aid. Aid was projectised and expected to deliver cost-effective and measurable results within a limited timeframe. The beginnings of the 'value for money' trend could be traced back to the early 1970s, but the gap between the ELT market and ELT in development widened under Thatcher (Brumfit 1997).

The Thatcher government was concerned with the ambiguity of ELT aid objectives and mandated that ELT should compete for funding with other areas of development aid on a geographical basis, which was a departure from ODM's (proclaimed) focus on the rural poor. ODA aid was allocated via a Country Review Paper (CRP), which outlined the rationale for UK investment following consultation with ODA officials and UK representation in-country. Although ODA acknowledged that to 'an extent sectoral allocations are part of an historical process', the CRP provided an opportunity for reassessing the distribution of aid (Iredale 1997a, 103). The shift in policy direction resulted in ELT largely being targeted to projects with an occupational purpose or as part of a national education system where English was the medium of instruction. In the words of ODA's Chief Educational Advisor, aid for ELT was required to demonstrate 'a clear enabling objective' related to matters 'that are less narrowly educational and more broadly developmental.' (Iredale 1997b, 127) Nonetheless, it was arguably easier for ELT than it was for some other areas of aid activity to demonstrate that the UK had a competitive advantage relative to other donors, and measurable results within the life of a project cycle. Thus ELT could demonstrate its 'value for money' in ways that 
were aligned with the embedded ideological views about the commercial advantages of English language competence.

ODA asserted that it 'had every confidence that our pre-eminence in ELT would ensure that our work in the English language field would prosper', and the increase in ELT posts after the KELT review gave weight to ODA's claims that it had 'effectively ensured that ELT cannot be singled out as a target for expenditure reduction.' (Iredale 1997b, 126) Therefore, despite the changed institutional context and overarching neoliberal agenda, the importance of aid for ELT continued to be 'recognised at the highest level in ODA'. (Iredale 1986)

Moreover, ODA perceived an additional benefit to ELT - increased language competence would positively reinforce other forms of assistance. An ODA review of ELT development aid in 1984 argued that: 'English is an indispensable tool for all development work, enabling Third World countries to interpret offers of aid from national and international agencies'. (Macmillan 1982) Similar assertions had been made by ODM during its first incarnation: 'it may be necessary to teach English to enable a developing country to obtain maximum benefit from some other form of British aid.' (The Ministry of Overseas Development 1967) Likewise, a report produced during ODM's existence in 1974-79 stated: 'Competency in English is also becoming increasingly necessary for a developing country's economy to enable it to interpret offers of aid from English-speaking donor countries, produce development plans, take part in negotiations for aid, obtain and maintain the appropriate capital items and make full use of offers of technical expertise.' (The Background to British Government-Financed ELT Work in Developing Countries 1973) In line with the prevailing language ideology, English was associated with national autonomy and competence in government.

Policy had long been framed by claims of an inexhaustible demand for ELT. Alternate governments aimed to maximise influence with limited resources by boosting national capacity, providing expertise, investing in learning materials and assisting with curriculum development. The Thatcher government had political reasons to claim the language of "value for money' as their own, but actually both ODM and ODA had consistently been concerned with the cost-effectiveness of ELT. Ideas about strategic prioritisation therefore became deeply embedded over decades. They formed part of the cognitive template of policy-makers alongside notions of moral duty and self-interest, to which we now turn. 


\section{Ideas of the National Interest and Moral Duty}

It was well understood from the establishment of ODM that an instrumentalist interpretation of Britain's interests would be key in funding decisions. However, instrumentalism was leavened with altruistic ideas about the purpose of development aid. The 1965 White Paper (Ministry of Overseas Development 1965) stated that the government expected the country's long-term interests would be served by aid policy, but also stressed Britain's moral obligation to assist countries struggling to make their way out of poverty. This was the first formal expression of the blend of moral duty and self-interest that would characterise British development aid over the decades (Burnell 1991). A parliamentary speech by Labour MP Roderick MacFarquhar illustrates the interplay of altruism and interest that was a common feature of debates on ELT policy: ' . . because it is advantageous to us and because we helped to make English a world language we have an interest and, indeed, a duty to help ensure that it is...spoken everywhere in intelligible forms.' (MacFarquhar 1977)

High-level political concern about preserving British influence after decolonisation paved the way for a period of 'intense cultivation of ELT' (Phillipson 1992, 113). The use of English as an international lingua franca was thought to promote stability and prosperity, as articulated in an ODM working party document: 'The advantage to Britain in contributing to the spread and improvement of the teaching and usage of English language in the developing world is manifest. It enables the developing Commonwealth countries to communicate with and trade with each other and with Britain. It contributes to the development of education generally and to the growth of technical expertise. It promotes friendship and understanding not only between developing countries but also with the more developed countries by providing a common language in which they can communicate.' (The Background to British Government-Financed ELT Work in Developing Countries 1973) The persistence of these presumptions is revealed by a report by an ODA/FCO/British Council working party, published nearly a decade later: 'The more widespread the use of English the more likely are we, the British, to benefit from the advantage of being able to conduct business in our mother tongue. It enables us to maintain our links with the Commonwealth; it helps us to strengthen links with other countries; it provides a medium for the better understanding and appreciation of Britain; and it facilities the development of friendly and cooperative relationships with political and commercial advantage to Britain...' (Macmillan 1982) It emphasises that 
providing ELT-related aid is not just a wise choice in terms of serving British interests, but it is also a moral duty: 'language is of central and crucial importance in development...it would be criminally neglectful to withhold the means of fostering and encouraging it.' (Macmillan 1982)

Successive governments were particularly invested in intra-Commonwealth communication. The British government, at a meeting of Commonwealth Prime Ministers, produced a memorandum that stated: 'Although, understandably the need for national languages is widely felt, English remains in many countries as a language of administration, law, industry, commerce and of education at higher levels. For those having no single indigenous tongue it provides an important internal bond and for all it is the most useful medium of international communications in politics, in commerce and, above all, in education and science...' (Commonwealth Secretariat 1968) In line with Anglocentric ideological views, English was portrayed as an international lingua franca shorn of historical and cultural meaning that provided an advantageous replacement for local languages. This narrative was not just crafted for an external audience; similar sentiments were also expressed internally, in even more assertive terms. For example, it was noted in an ODM briefing paper that African 'indigenous languages are ill-adapted to the requirements of modern technological society. Indeed, it is only through possession of a European language that their administrators, businessmen, engineers and technicians can gain access to the knowledge needed for further development and improved living standards.' (Smith 1968) For the newly-independent African countries, European languages such as English, 'probably indeed provides the only medium through which an advance can be made from tribal separation to national self-consciousness.' (Smith 1968) Another illustrative example can be found in the correspondence of the Parliamentary Private Secretary to the Foreign Secretary, Roderick MacFarquhar, with ODM. He expressed his support for aid for ELT in terms that revealed presumptions of the cultural and political 'neutrality' of English. Reflecting on his personal experience in Nigeria, he remarked: 'in an era when language is often an emotive nationalist symbol, it is often only by using a neutral external language for internal communication that the language issue can be resolved.' (Tomlinson 1977) The legacy of colonialism in shaping policy was starkly apparent. Ideas about the superiority of Western models of development rested on narratives of the 'deficiencies' of non-Western states. 
The FCO and overseas diplomats chose to appeal to the same blend of duty-based and selfinterested reasoning when they appealed for funds for ELT, seemingly judging that such a frame would resonate within ODM/ODA. The archive contains plentiful examples of diplomatic dispatches arguing in favour of increased ELT support. The topic of English language centres provides a good example of how FCO interventions in support of policy initiatives were framed over the years. When ODM was established in 1964, an official from the Embassy in the Congo took an early opportunity to lobby on behalf of a proposal to build an English language centre: 'This is one of the few things which the British are especially equipped to do in the Congo and which, in my opinion, we ought to do in our own interest and also in the wider interest of African unity'. (Millard 1964) Potential benefits were presented as political and economic, with long-term advantages for the UK: 'We have a real interest in seeing that these future managers start right with a bias towards British goods and British methods.' (Millard 1964) Even at this early stage, it possible to identify ideas about how ELT could promote national security, including by Britain's rivals: 'The degree of interest which the Congolese show in learning English was apparently recognised by the Russian Embassy. Before they left we understand that they had plans to teach the Congolese English and get across their message that way.' (Millard 1964)

Turning to the height of the Cold War in the mid-1980s, ELT continued to be discussed as a security issue. Senior figures pressed for increased expenditure as a bulwark against Soviet influence. The Cultural Relations Department strongly supported a project to establish an English Language Centre in the University of Sana'a in Yemen, emphasising the opportunity it provided to reach the emergent elite: 'The English Language Centre is potentially our more important development project in the YAR, not least because many of those who study there are likely to be the YAR's future leaders... If we do not provide the service, there is every likelihood that the Yemenis will turn to others, particularly the Soviet Union, for training in numerous key areas of Yemeni development. This, from our point of view, would be highly undesirable.' (Macrae 1982) The then Minister for Europe, Douglas Hurd, wrote to Neil Marten, the Minister for Overseas Development, to strongly endorse the FCO's stance: 'There are powerful political reasons for our whole-hearted involvement in this project. Our aid programme is a very important element in our strategy to stem Soviet influence, and [ELT] is the core of our aid.' (Hurd 1982) The correspondence underlines the ideas of realpolitik that shaped decisions regarding ELT in geopolitically strategic areas. 
Internal ODA correspondence reveals that appeals for English language support did not always meet a sympathetic audience. The Ambassador to Vietnam requested assistance for the establishment of an ELT institute, leading an official to remark: 'It is flattering to hear that the Vietnamese prefer English to American English but the fact is that, by agreement between the British Council (as HMG's agent in these matters) and the State Department, Vietnam is an "American" region for ELT aid work.' (Moisley 1969) ODA were careful to ensure that English language promotion did not disrupt diplomatic relations with important allies. Another example of this diplomatic sensitivity occurs in correspondence relating to proposals for the opening of an ELT institute in Laos: 'If we went ahead on these lines, we would have to be careful not to offend American susceptibilities... And we might have to be prepared for some resistance from the French, who have a passionate desire to keep Laos in the Francophone world.' (Rae 1968) Where moral duty and self-interest were perceived to be in conflict, strategic interpretations of the national interest prevailed.

Decisions regarding aid for ELT were shaped by perceptions of Britain's political and economic interest, particularly in terms of projecting soft power in the Commonwealth. Key actors in the FCO used their influence to advocate in favour of foreign policy objectives. The conviction that ELT could serve national interests was a defining feature of policy-making across Labour and Conservative governments. Aid for ELT was also justified in official documents and public statements by appealing to notions of Britain's historic duty to help the poorest. The altruistic narrative only worked by tapping into a language ideology that presented English as an unproblematic good.

\section{Conclusion}

Despite administrative overhauls and a shifting political environment, development aid for ELT remained a key element of the UK's overseas assistance programme for decades. This article uses constructivist institutionalism to analyse archival material from 1964-1986, in order to understand the deeply embedded ideas that guided and framed ELT policy over time.

The archives contain rich insights in this regard. There was widespread agreement that it was wise to target aid strategically to maximise impact. Aid for ELT was targeted at national elites to exert maximum leverage, and focussed on teacher training and curriculum development to achieve a multiplier effect. There were common perceptions of the national 
interest (at least in regards to ELT) across governments, the Foreign and Commonwealth Office and the civil service. English was thought to be essential for maintaining influence in Commonwealth territories and projecting soft power. Funding for ELT was seen to provide political and commercial dividends. In addition, it was claimed that English had the potential to help the poorest work their way out of poverty and that Britain had a moral obligation to provide this assistance, particularly for Commonwealth countries. A unifying theme of discussions concerning ELT was a metanarrative that held that English was the tongue of political, economic, scientific and technological progress. It was thought to have the potential to unite culturally diverse territories and promote regional and international stability. Contemporaneous political, economic and cultural trends provided empirical weight to this language ideology. The world order became increasingly Anglophone due to the rise of American hegemony, and representatives from developing countries appealed for aid for ELT in order to adapt to this linguistic reality. This range of ideas became deeply entrenched and formed the cognitive template through which the political elite assessed the benefits of funding ELT. Thus, the informal convention of allocating aid for ELT persisted despite the organisational turbulence at ODM/ODA. Policy was ideationally path-dependent.

The archival material uncovers the role that individuals have played in the construction of this worldview, and so underlines the salience of agency in understanding the development of policy pathways. The article has encompassed the voices of various ministers, politicians, and officials who have made interventions that have reinforced the cognitive template that prevailed during this period. The strong similarities in rationale for ELT-related aid over the decades underline the resilience of such perceptions.

A cautionary note is appropriate at this point. It is important to be mindful of the context and subjective understandings that inform the content of primary sources, and to ask to what extent they can be regarded as reliable indicators of an intersubjective worldview. The sources are written for a range of audiences and for a variety of purposes. Some were written for the international stage (for example, Commonwealth conferences) and some for parliamentary business (for example, working party reports and responses to questions from MPs), and so the authors might be expected to put a positive spin on Britain's development interventions. Several quotes are taken from private correspondence between civil servants and politicians, where confidentiality could permit candid conversations to take place. Some extracts are taken from proposals arguing in favour of a new ELT initiative, which may have 
been coloured by the author's agenda to secure increased funding. Other extracts include more reflective statements about ELT, which were written in the absence of an imminent funding opportunity. What is striking is that very similar messages are conveyed by different authors in dissimilar contexts. Through the lens of constructivist institutionalism, the common themes across a vast range of material suggests the presence of a cognitive template about the benefits of funding ELT. Future research could test this proposition by interviewing former politicians and retired officials. These figures no longer have professional incentives to extol the virtues of ELT, and so it would be intriguing to explore whether they espouse views similar to those expressed in the archival documents.

A limitation of the article is that it is not supplemented by comprehensive, real-term figures of the total amount of aid given to ELT activities during this period. I could not locate such figures, despite helpful consultations with the archivist of the University of Warwick ELT Archive (personal correspondence, 1 July 2017). Assistance for ELT was provided through various means. It constituted the direct provision of ELT-trained personnel, as well as salarysupplemented teachers, British Council staff, volunteers, subsidised book schemes, library development schemes and funded TV and radio programmes. To quote ODM correspondence, 'it is impossible to quantify the cost of all this support so as to make a sensible comparison' with figures of previous years, seeing as funding was so widely disbursed (Tomlinson 1977). Future research could investigate the feasibility of collecting such data, as the distribution of funding would surely reveal important insights into political priorities.

Future research could use a similar framework to this article to investigate the extent to which ideational path-dependency can account for the framing and design of contemporary UKfunded ELT initiatives (for example, DFID-funded schemes such as English for Education College Trainers in Myanmar, the English Language Tanzania Project and English in Action in Bangladesh). It would also be interesting to conduct comparative studies with language education initiatives funded by other donors. For example, France has long been very active in funding French language education programmes in the developing world. Is it possible to identify a cognitive template about language education amongst the French political elite, and if so, how does it compare with the British? It is reasonable to expect that the French would share similar concerns with maintaining influence in former colonial territories. However, the rise of an Anglophone world order has very different connotations for French language education than it does for ELT, and so we might expect to see French policy framed in ways 
very distinct from the British (Wright 2016, 148-152). Such research would enhance our understanding of the ideational foundations of language education initiatives in development aid. It would also test the utility of a constructivist institutionalist lens in interpreting the historical and ideational dynamics that shape policy pathways.

Appleby, R. (2010) ELT, Gender and International Development. Bristol: Multilingual Matters.

Barder, O. (2005) Reforming Development Assistance: Lessons from the UK Experience. Available at: https://www.cgdev.org/publication/reforming-development-assistance-lessonsuk-experience-working-paper-70 (accessed 6 September 2018).

Bell, S. (2011) 'Do we really need a new 'constructivist institutionalism' to explain institutional change?' British Journal of Political Science 41(4): 883-906.

Boyle, J. (2010) 'Imperialism and the English Language in Hong Kong.' Journal of Multilingual and Multicultural Development 18(3): 169-181.

Blyth, M. (2002) Great Transformations: Economic Ideas and Institutional Change in the Twentieth Century. Cambridge: Cambridge University Press.

British Council and Ministry of Overseas Development Working Party (1966, 1 February) Ministry of Overseas Development Brief for Meeting. OD17/320 The Teaching of English as a Second Language - Policy. The National Archives, Kew.

Brumfit, C. (1997) 'Foreword', in Abbott, G. and C. Beaumont (eds) The Development of ELT: The Dunford Seminars, 1978-1993, pp. xii-xix, Hemel Hempstead: Prentice Hall.

Burnell, P. J. (1991) 'Introduction to Britain's overseas aid since 1979: between idealism and self-interest', in Bose, A. and P. J. Burnell (eds) Britain's Overseas Aid Since 1979: Between Idealism and Self-Interest, pp. 1-31. Manchester: Manchester University Press.

Coleman, H. (2010) The English Language in Development. London: British Council. 
Coleman, H. (2011) 'Developing Countries and the English Language: Rhetoric, risks, roles and recommendations', in Coleman, H. (eds) Dreams and Realities: Developing Countries and the English Language, pp. 11-24. London: British Council.

Commonwealth Secretariat (1968, 21 November) Meeting of Commonwealth Prime Ministers, January 1969. Memorandum by the British Government. FCO 68/156 Commonwealth Initiatives: English in the Commonwealth. The National Archives, Kew.

Cox, R. H. (2004) 'The path-dependency of an idea: why Scandinavian welfare states remain distinct', Social Policy and Administration 38(2): 204-219.

Douglas, A. J. A. (1975, 20 August) Letter to Luce and MacFarquhar. OD 17/691 English Language Teaching Policy. The National Archives, Kew.

Dua, H. R. (1996) 'The spread of English in India: Politics of language conflict and language power', in Fishman J. A., A. W. Conrad and A. Rubal-Lopez (eds) Post-imperial English: Status Change in Former British and American Colonies, 1940-1990, pp. 557-588. New York: Mouton de Gruyter.

Evans, S. (2002). ‘Macaulay’s Minute Revisited: Colonial Language Policy in Nineteenthcentury India.' Journal of Multilingual and Multicultural Development 23(4): 260-281.

Erling, E. J. and Seargeant, P. (eds) (2013) English and Development: Policy, Pedagogy and Globalization. Bristol: Multilingual Matters.

Hall, P. A. and Taylor, R. C. (1996) Political science and the three new institutionalisms. Political Studies, 44(5): 936-957.

Hay, C. (2006) 'Constructivist Institutionalism', in Rhodes, R. H., S. A. Binder and B. A. Rockman (eds) The Oxford Handbook of Political Institutions, pp. 56-74. Oxford: Oxford University Press. 
Hay, C. (2010) 'Ideas and the Construction of Interests', in Beland, R. and R. H. Cox (eds) Ideas and Politics in Social Science Research, pp. 65-82. Oxford: Oxford University Press.

Hay, C. (2016) 'Good in a crisis: the ontological institutionalism of social constructivism.' New Political Economy 21(6): 520-535.

Hewitt, A. (1978) 'British Aid: Policy and Practice'. ODI Review 2: 55-66.

Hurd, D. (1982, 25 June) Letter to Rt Hon Neil Marten MP. FCO 8/4871 English Language Projects in YAR. The National Archives, Kew.

Iredale, R. (1986, October 17) Report on Britain's support for the learning of English. OD 52/88 English Language Teaching - Policy. The National Archives, Kew.

Iredale, R. (1997a) 'Investing in Education', in Abbott G. and C. Beaumont (eds) The Development of ELT: The Dunford Seminars, 1978-1993, pp.101-105. Prentice Hall: Hemel Hempstead.

Iredale, R. (1997b) 'The English language as aid', in Abbott, G. and C. Beaumont (eds) The Development of ELT: The Dunford Seminars, 1978-1993, pp.126-127. Prentice Hall: Hemel Hempstead.

Ireton, B. (2013) Britain's International Development Policies: A History of DFID and Overseas Aid. Basingstoke: Palgrave.

Johnson, D. C. (2013) Language Policy. Basingstoke: Palgrave.

Killick, T. (2005) 'Policy autonomy and the history of British aid to Africa'. Development Policy Review 23(6): 665-681.

Louw, P. E. (2010). 'Anglicising Postapartheid South Africa.' Journal of Multilingual and Multicultural Development 25(4): 318-332. 
MacFarquhar, R. (1977, 28 July) Debate on English Language Teaching Overseas. OD 52/35 English Language Teaching Policy. The National Archives, Kew.

Macmillan, M. (1982, October 18) ODA Evaluation of the Key English Language Teaching (KELT) Scheme. OD 52/81 Evaluation of the KELT Scheme. The National Archives, Kew.

Macrae, J. E. C. (1982, 24 June) Letter to Underwood. FCO 8/4871 English Language Projects in YAR. The National Archives, Kew.

Millard, G. E. (1964, 24 July) Letter from British Embassy in Leopoldville. FO 371/176735 Overseas Refugees Charities. The National Archives, Kew.

Ministry of Overseas Development (1965) Overseas Development: the work of the new ministry. London: HMSO.

Ministry of Overseas Development (1975) The Changing Emphasis in British Aid Policies: More Help for the Poorest. London: HMSO.

Moisley, H. A. (1969, 11 September) Letter to Rednall. OD17/673 English as Foreign Language. The National Archives, Kew.

Overseas Development Administration and British Council (1971, October) The setting up of an English as a Foreign Language scheme. OD17/673 English as Foreign Language. The National Archives, Kew.

Parsons, C. (2016) 'Ideas and power: four intersections and how to show them.' Journal of European Public Policy 23(3): 446-463.

Pennycook, A. (2014) The cultural politics of English as an international language. London: Routledge.

Phillipson, R. (1992) ‘ELT: the native speaker’s burden?’ ELT Journal 46(1): 199-212. 
Phillipson, R. (2006) 'Language policy and linguistic imperialism', in Ricento, T. (ed) An Introduction to Language Policy: Theory and Method, pp.346-361. Oxford: Blackwell.

Rae, C. R. A. (1968, 17 December) Memo to Maguire. OD 35/84 English Language Teaching Laos. The National Archives, Kew.

Ricento, T. (2000) Ideology, politics and language policies: Focus on English. Amsterdam/Philadephia: John Benjamins.

Robson, J. A. (1981, 17 March) Letter to Luce from Robson of East Africa Department. FCO 106/372 English Language Teaching in Burundi. The National Archives, Kew.

Ross, F. (2013) 'Bringing political identity into discursive and ideational analysis: Welfare reform in Britain and the United States'. British Politics 8(1): 51-78.

Schmidt, V. A. (2008) 'Discursive institutionalism: The explanatory power of ideas and discourse'. Annual Review of Political Science 11: 303-326.

Sharland, E. J. (1981, 17 March) Letter to Finch. FCO 106/372 English Language Teaching in Burundi. The National Archives, Kew.

Sharp, D. J. (1981, 25 February) Letter to Sharland. FCO 106/372 English Language Teaching in Burundi. The National Archives, Kew.

Silverstein, M. (1976) 'Language Structure and Linguistic Ideology', in Clyne P., W. F. Hanks and C. L. Hofbauer (eds) The Elements: A Parasession on Linguistic Units and Levels, pp.193-247. Chicago: Chicago Linguistic Society.

Smith, D. M. (1968) English language teaching in Francophone countries. FCO 25/781 English Language Training Centre. The National Archives, Kew.

Smith, R. C. (2016) ELT and the British Council, 1934-2014: Research Notes. Available at: http://www2.warwick.ac.uk/fac/soc/al/research/collections/elt_archive/research_projects/briti shcouncil/ (accessed 6 September 2018). 
Taylor (1965, 28 May) Letter from the Parliamentary Under-Secretary of State to the Minister of Overseas Development. OD17/320 The Teaching of English as a Second Language - Policy. The National Archives, Kew.

Tollefson, J. W. (2015) 'Historical-Structural Analysis.', in Hult, F. M. and Johnson, D. C. (eds) Research Methods in Language Policy and Planning: A Practical Guide. Chichester: John Wiley \& Sons.

The Background to British Government-Financed ELT Work in Developing Countries (1973) OD17/696 English Language Teaching, Working Party Report (first revised version British Council final). The National Archives, Kew.

The Ministry of Overseas Development (1967) OD 17/442 Teaching of English as a Second Language General. The National Archives, Kew.

Tomlinson, J. E. (1977, 25 August) Letter to MacFarquhar. OD 52/35 English Language Teaching Policy. The National Archives, Kew.

Tupas, R. (2014). 'The politics of ' $p$ ' and ' $\mathrm{f}$ ': a linguistic history of nation-building in the Phillipines'. Journal of Multilingual and Multicultural Development 36(6): pp.587-597.

Turner, A. M. (1971) English as a Foreign Language (EFL). OD17/673 English as Foreign Language. The National Archives, Kew.

Wendt, A. (1999) Social Theory of International Politics. Cambridge: Cambridge University Press.

Wiley, T. G. (2006) 'The lessons of historical investigation: Implications for the study of language policy and planning', in Ricento, T. (ed) (2006) An Introduction to Language Policy: Theory and Method, pp. 135-152. Oxford: Blackwell. 
Winpenny, J. T. (1991) 'Efficiency and Effectiveness in the Overseas Development Administration', in Bose, A. and P. J. Burnell (eds) Britain's Overseas Aid Since 1979:

Between Idealism and Self-Interest, pp.32-48. Manchester: Manchester University Press.

Wright, S. (2016) Language Policy and Language Planning: From Nationalism to Globalisation. Basingstoke: Palgrave. 